\title{
TERIPANG: POTENSINYA SEBAGAI BAHAN NUTRACEUTICAL DAN TEKNOLOGI PENGOLAHANNYA
}

\author{
Theresia Dwi Suryaningrum*
}

\begin{abstract}
ABSTRAK
Teripang atau sea cucumber merupakan hewan laut yang telah dimanfaatkan sebagai bahan pangan dan obat. Kandungan nutrisinya yang lengkap, secara tradisional telah dimanfaatkan sebagai bahan nutraceutical untuk melancarkan peredaran darah akibat penyempitan pembuluh darah karena kolesterol, melancarkan fungsi ginjal, meningkatkan metabolisme, mencegah penyakit arthritis, diabetes melitus, hipertensi, mempercepat penyembuhan luka, dan antiseptik tradisional. Karena manfaatnya yang cukup luas, kini produk olahan teripang semakin berkembang seperti ekstrak teripang dalam bentuk jelly dan tablet yang digunakan sebagai suplemen. Indonesia sebagai negara yang kaya akan keanekaragaman jenis teripang dan pengekspor teripang terbesar di dunia, saat ini belum memiliki industri yang mengolah teripang menjadi ekstrak teripang sebagai bahan nutraceutical. Sampai saat ini teknologi pengolahan teripang baru dalam bentuk kering dan dimanfaatkan sebagai bahan pangan. Sementara penelitian teripang sebagai bahan obat masih terbatas dan produk ekstrak teripang masih diimpor dari Malaysia dan Amerika. Mengingat sumberdayanya yang cukup potensial, maka penelitian ke arah bidang farmasi dan kesehatan perlu ditingkatkan. Penelitian tersebut untuk mendukung industri farmasi yang mengolah teripang menjadi bahan nutraceutical yang pasarnya masih terbuka serta peningkatan nilai tambahnya cukup tinggi.
\end{abstract}

KATA KUNCI: teripang, bahan nutraceutical, teknik pengolahan

\section{PENDAHULUAN}

Teripang atau yang dikenal sebagai mentimun laut atau sea cucumber termasuk hewan laut yang berbadan lunak yang berbentuk memanjang seperti mentimun. Hewan ini termasuk dalam kelas Holothuroida dari bangsa Echinodermata yang merupakan hewan tidak bertulang belakang dan bertubuh lunak atau berduri. Bangsa Cina menyebutnya dengan haisom yaitu makanan istimewa yang biasanya dihidangkan sebagai hidangan para bangsawan pada saat pesta perkawinan atau hari istimewa seperti imlek. Teripang yang dimasak dengan sirip ikan hiu dan sarang burung, diyakini oleh sebagian orang sebagai makanan yang dapat mencegah penyakit dan digunakan sebagai obat penguat (tonikum).

Kandungan nutrisinya yang lengkap menyebabkan teripang sering disebut sebagai ginseng dasar laut dan menjadi suplemen yang mujarab. Pada pengobatan Cina tradisional, teripang diketahui bermanfaat untuk melancarkan peredaran darah, mencegah penyempitan pembuluh darah akibat kolesterol, melancarkan fungsi ginjal, meningkatkan metabolisme, mencegah penyakit arthritis, diabetes melitus, hipertensi, mempercepat penyembuhan luka, dan antiseptik tradisional (Zhang, 1988). Air rebusan teripang telah dimanfaatkan secara tradisional sebagai tonikum dan diberikan kepada wanita yang baru melahirkan untuk menghentikan perdarahan dan mempercepat proses penyembuhan luka khitan pada anak laki-laki (Fitriani, 2006).

Dewasa ini ekstrak teripang telah dipasarkan dalam bentuk jelly, kapsul atau tablet, dan digunakan sebagai obat untuk menyembuhkan berbagai macam penyakit atau suplemen nutrisional. Berdasarkan kesaksian dari beberapa orang yang telah mengkonsumsi teripang, dilaporkan bahwa ekstrak teripang dapat menyembuhkan penyakit lupus, diabetes, jantung koroner, nyeri sendi/ rematik, ginjal, asma, hepatitis, dan lain-lainnya (Hermansyah et al., 2006; Fitriani, 2006). Hasil analisis laboratorium menunjukkan bahwa ekstrak teripang kering mengandung protein sampai $86,8 \%$, kolagen $80 \%$, mineral, mukopolisakarida, glukoaminoglikan (GAG), antiseptik alamiah, kondroitin, Omega 3, omega 6, dan omega 9, serta berbagai asam amino (Anon., 2007a). Glukosamin dan kondroitin dapat memulihkan penyakit-penyakit sendi serta membantu pembentukan tulang rawan. Di Jepang, kondroitin sulfat telah dipatenkan dan diklaim sebagai obat penghambat virus untuk terapi HIV (Darmananda, 2002).

Selama ini sebagian besar teripang di Indonesia diolah menjadi teripang kering dan diekspor ke berbagai negara. Industri pengolahan ekstrak teripang

*) Peneliti pada Balai Besar Riset Pengolahan Produk dan Bioteknologi Kelautan dan Perikanan 
menjadi suplemen atau bahan nutraceutical belum ada di Indonesia, padahal nilai tambah yang diperoleh lebih tinggi bila dibandingkan dengan teripang kering. Sementara produk ekstrak teripang yang digunakan sebagai makanan suplemen atau nutraceutical masih diimpor dari Malaysia dan Amerika. Permintaan ekstrak teripang cukup tinggi, volume penjualan produk tersebut meningkat setiap tahunnya sejak teripang dipasarkan di Indonesia (Daryatmo, 2006). Mengingat pasarnya yang cukup terbuka, maka seharusnya industri farmasi yang mengolah produk tersebut dapat diupayakan di Indonesia. Oleh karena itu, upaya budidaya teripang perlu disosialisasikan sehingga selain untuk mengembangkan industri farmasi di dalam negeri diharapkan dapat mengentaskan kemiskinan nelayan di daerah pesisir.

\section{JENIS-JENIS DAN PERANAN TERIPANG DI ALAM}

Teripang telah dimanfaatkan sejak zaman purba, bukan saja oleh masyarakat Cina dan Korea tetapi juga masyarakat Malaysia. Penggunaan teripang emas (Stichopus hermanii) sebagai antiseptik tradisional dan obat serbaguna untuk berbagai penyakit telah dilakukan sejak 500 tahun yang lalu pada masyarakat Pulau Langkawi di Semanjung Malaysia (Fitriani, 2006).

Di dunia ada 1.250 spesies teripang yang telah dideskripsikan, sedangkan di Indonesia ada 25 jenis yang mempunyai nilai komersial yang berasal dari perairan karang di Indonesia (Darsono, 2005). Umumnya jenis teripang komersial hidup pada substrat pasir, substrat keras, atau substrat karang pada perairan dangkal sampai kedalaman $50 \mathrm{~cm}$. Jenis-jenis teripang yang dipasarkan di Indonesia dan nilai pasarnya dapat dilihat pada Tabel 1 .

Teripang berperan penting sebagai pemakan deposit dan pemakan suspensi. Hewan ini mencerna sejumlah besar sedimen, yang memungkinkan terjadinya oksigenasi pada lapisan atas sedimen. Tingkah laku teripang yang mengaduk dasar perairan untuk mendapatkan makanannya membantu menyuburkan substrat disekitarnya. Proses tersebut mampu mencegah terjadinya penumpukan bahanbahan organik dan sangat mungkin membantu mengontrol populasi hama dan organisme patogen bakteri tertentu. Teripang juga berperan penting dalam rantai makanan bagi berlangsungnya kehidupan berbagai jenis biota lain. Teripang dalam rantai pangan berperan sebagai penyumbang pakan berupa telur dan larva bagi organisme lain seperti krustasea, moluska, maupun ikan (Darsono, 2005).

\section{PRODUKSI DAN PERDAGANGAN TERIPANG}

Pemanfaatan teripang secara domestik relatif sangat sedikit dan mungkin tidak signifikan dalam nilai dan jumlah. Menurut Data Pusat Statistik Perikanan Indonesia tahun 2007 (Dep KP), produksi teripang selama periode $2001-2005$ naik sebesar $3,58 \%$. Kenaikan signifikan terjadi pada tahun 2004 yaitu dari 3.014 ton pada tahun 2003 naik menjadi 6.930 ton pada tahun 2004 dan pada tahun 2005 naik menjadi 7.178 ton. Di Indonesia teripang biasanya diolah dalam bentuk kering, asap, kerupuk teripang, dan diekspor dengan negara tujuan Singapura,

Tabel 1. Jenis-jenis teripang di Indonesia dan nilai pasarnya

\begin{tabular}{lllc}
\hline No & \multicolumn{1}{c}{ Jenis/spesies } & \multicolumn{1}{c}{ Nama daerah } & Tingkat harga \\
\hline 1 & Holothuria scraba & Teripang pasir putih & Mahal \\
2 & H. nobilis & Teripang koro/susu hitam & Mahal \\
3 & Thelonata ananas & Teripang nanas putih & Mahal \\
4 & H. fuscogilva & Teripang susu putih & Mahal \\
5 & Stichopus variegatus & Teripang gama & Sedang \\
6 & Actinopyga lecanora & Teripang batu & Sedang \\
7 & A. milliaris & Teripang lontong & Sedang \\
8 & H. edulis & Teripang merah & Murah \\
9 & H. leucospilota & Teripang hitam & Murah \\
10 & H. atra & Teripang keling & Murah \\
\hline
\end{tabular}

Sumber: Darsono (2005). 
Hongkong, dan Taiwan. Seperti yang dilaporkan oleh Conand dalam Darsono (2005), Hongkong merupakan pasar utama teripang, pemasok utamanya adalah Indonesia dan Filipina. Perdagangan teripang dilakukan oleh para eksportir yang mendapat pasokan dari para tengkulak/pengumpul. Namun produk teripang dari Indonesia dikategorikan berkualitas rendah. Keadaan ini disebabkan oleh karena penanganan pascapanen produk teripang yang kurang baik. Teripang biasanya dimasak sebagai sup atau salad dan dihidangkan pada saat pesta. Masyarakat Cina yakin bahwa dengan makan teripang, maka lemak akan diserap sehingga dapat mencegah pembentukan kolesterol dalam darah.

Jenis teripang yang sudah dibudidayakan adalah teripang pasir. Daerah yang sudah membudidayakan teripang tersebut antara lain Sulawesi Tenggara, Lampung, dan Nusa Tenggara Barat. Teripang dipelihara di laut dengan sistem "pen" (kurungan) atau dapat juga dipelihara di dalam kolam air laut (tambak). Kendala yang dihadapi adalah belum tersedianya benih teripang. Walaupun pembenihan teripang sudah berhasil dilakukan di Balai Besar Pengembangan Budidaya Laut Lampung, namun hasilnya belum dapat dilakukan secara massal. Saat ini benih teripang untuk budidaya masih diperoleh dari hasil penangkapan di alam (Murdjiyo, 1997).

\section{KANDUNGAN NUTRISI TERIPANG}

Teripang mengandung berbagai macam senyawa yang besarnya bervariasi tergantung spesiesnya. Jenis teripang yang banyak digunakan sebagai obat dan makanan adalah Stichopus chloronatus, S. hermanii, S. variegatus., dan S. japonicus. Menurut Departemen Obat dan Makanan Amerika Serikat (USDA), teripang memiliki kandungan gizi yang lengkap, antara lain 9 jenis karbohidrat, 59 jenis asam lemak, 19 jenis asam amino, 25 komponen vitamin, 10 jenis mineral, dan 5 sterol (Anon., 2006b). Teripang kering mempunyai kandungan nutrisi sebagai berikut: kadar air 8,90 \%; protein 82,0\%; lemak 1,70\%; abu 8,60\%; karbohidrat 4,80\%; Vitamin A $455 \mu \mathrm{g} \%$; vitamin B (thiamine) $0,04 \mathrm{mg} \%$; niacin $0,4 \mathrm{mg} \%$; riboflavin 0,07mg\%; dan kalori $365 \mathrm{cal} / 100 \mathrm{~g}$ (Anon., 2007a). Walaupun kandungan lemaknya cukup rendah, namun teripang mengandung asam lemak multitetradonik penghambat enzim lipoksigenase yang memacu kerusakan saluran pernafasan penyebab asma (Darmananda, 2002). Hasil penelitian Fredalina et al. (1999) menunjukkan bahwa ekstraksi asam lemak teripang jenis Stichopus chloronotus mengandung 11 jenis asam lemak dengan berbagai macam pelarut etanol, metanol, dan bufer fosfat. Ekstraksi dengan menggunakan bufer fosfat menghasilkan asam eicosapentaenoat (EPA) sebesar $25,69 \%$ dan asam dokosaheksaenoat (DHA) sebesar $3,63 \%$. Sedangkan jika ekstraksi dilakukan dengan menggunakan air diperoleh DHA sebesar $57,55 \%$ dan EPA sebesar 7,84\%. Berdasarkan kandungan asam aminonya, teripang mengandung asam amino lebih tinggi bila dibandingkan dengan ikan laut, ayam, dan telor (Anon., 2006b). Teripang mengandung kolagen yang cukup tinggi yaitu sebesar $86 \%$ serta berbagai jenis mineral seperti kalsium, fosfat, fosfor, kromium, magnesium, besi, natrium, dan yodium. Dalam seratus gram bobot kering, daging teripang mengandung kalsium $118 \mathrm{mg}$, fosfor $22 \mathrm{mg}$, besi 14 $\mathrm{mg}$, dan yodium 0,6 $\mathrm{mg}$ (Darmananda, 2006).

\section{TERIPANG SEBAGAI BAHAN NUTRACEUTICAL}

Habitat teripang yang berupa karang memungkinkan teripang kaya akan berbagai macam mineral seperti kalsium dan fosfor yang penting

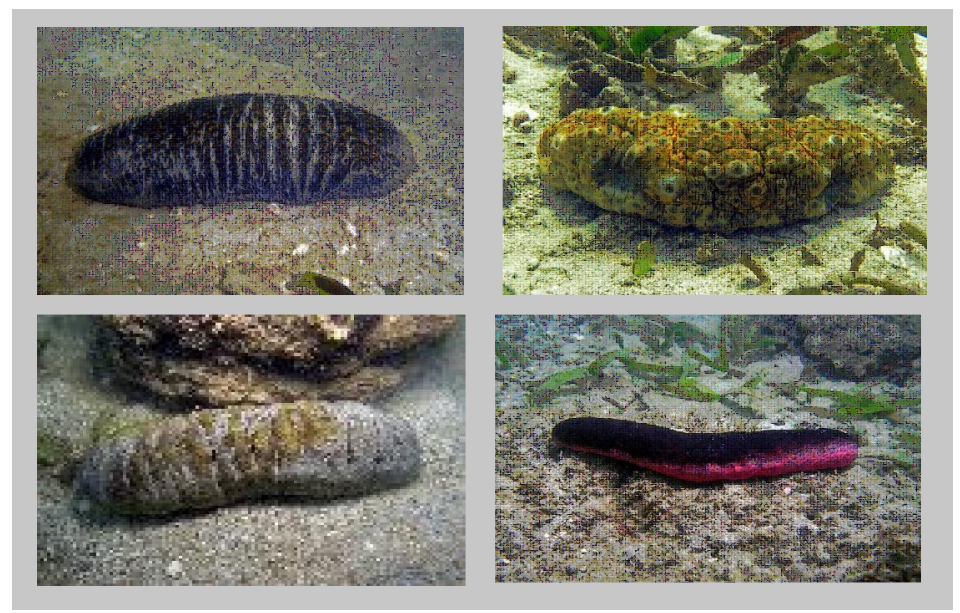

Gambar 1. Jenis-jenis teripang (searah jarum jam), teripang pasir (Holothuria scraba), dan teripang emas (Stichopus hermanii), teripang merah (H. edulis), teripang koro (H. nobilis). Sumber: Marine Species Fish Gallery, 2008. 
bagi perkembangan tulang dan gigi. Teripang juga kaya akan zat besi yang dibutuhkan untuk melakukan pembentukan sel darah merah, serta kalium penting dalam pencegahan dan perawatan hipertensi. Salah satu unsur mineral yang penting adalah kromium yang mampu merangsang kelenjar pankreas untuk menghasilkan insulin. Insulin merupakan senyawa yang dapat menyerap kelebihan glukosa dalam darah, sehingga ekstrak teripang dapat membantu para penderita diabetus melitus untuk mempertahankan kadar glukosa dalam darah, sedangkan yodium dapat mencegah penyakit gondok (Admin, 2008).

Kemampuan teripang dalam meregenerasi sel menjadi dasar utama bahwa teripang dapat menyembuhkan luka. Hidup di lingkungan yang keras seringkali menyebabkan dinding tubuh teripang terpecah atau luka pada organ tubuhnya. Namun teripang dapat meregenerasi dirinya sendiri dalam waktu 10-90 hari sehingga utuh kembali. Hal ini disebabkan oleh adanya faktor regenerasi sel (cell growth factor), yang mampu merangsang regenerasi untuk pemulihan sel atau jaringan tubuh yang rusak. Kandungan protein teripang yang tinggi dapat meningkatkan regenerasi sel-sel mati akibat luka sehingga mampu menyembuhkan luka. Selain itu, protein dapat juga berfungsi untuk memperkuat sistem daya tahan tubuh serta menghasilkan hormon dan enzim untuk melancarkan metabolisme (Lehninger, 1994). Kolagen yang merupakan jaringan pengikat dalam tulang dan kulit dapat dimanfaatkan untuk kecantikan kulit serta dapat meningkatkan regenerasi sel-sel mati akibat luka sehingga dapat mempercepat penyembuhan. Oleh karena itu, teripang dapat dimanfaatkan sebagai kosmetik dan salep untuk menyembuhkan luka. Dalam pertumbuhan tulang diperlukan suplemen kalsium, fosfat, dan kolagen sebagai jaringan pengisi, sehingga tanpa kolagen tulang akan rapuh dan mudah pecah. Kolagen bersama dengan kondroitin sulfat membentuk masa tulang rawan yang baru, sehingga dapat mengurangi sakit karena radang sendi (Lehninger, 1994). Kandungan asam lemak teripang seperti asam eicosapentaenoat (EPA, $20: 5 \omega 3$ ) dan asam dokosaheksaenoat (DHA $22: 6 \omega 3$ ) yang tergolong dalam $\omega 3$ HUFA merupakan asam lemak yang sangat diperlukan oleh tubuh kita. Kedua asam lemak ini dilaporkan mampu mencegah timbulnya penyakit kardiovasculer, diabetes, dan tekanan darah tinggi. Secara khusus EPA dapat menurunkan jumlah fibrinogen sehingga kekentalan darah menurun dan membuat aliran darah lebih baik. EPA juga dapat menurunkan kadar lemak dalam darah sehingga mengkonsumsi ekstrak teripang dapat mencegah penyakit arterosklerosis, sedangkan DHA berperan utama dalam perkembangan sistem syaraf dan dapat meningkatkan kemampuan memori dan daya pembelajaran, serta berfungsi sebagai anti alergi (Alimudin, 2006).

Teripang mengandung mukopolisakarida berupa glikosamin sulfat dan kondroitin sulfat. Glukosamin adalah suatu unsur pokok dari glikoprotein, proteoglikan, dan glikoaminoglikan yang berperan dalam sintesis proteoglikan (Lehninger, 1994). Menurut Hamijoyo (2003) glukosamin dapat menurunkan proses proteolitik kartilago dan membentuk kembali glukaminoglikan yang rusak. Di samping itu, senyawa ini dapat mencegah terjadinya penggumpalan dan pembekuan darah. Pada konsentrasi $5 \mu \mathrm{g} / \mathrm{ml}$, glukoaminoglikan mampu menyembuhkan stroke isemik otak dan penyakit jantung isemik. Kinerjanya dengan menghambat aktivitas pembekuan darah melalui penghambatan monomer fibrin dan meningkatkan aktivitas plasmin. Plasmin merupakan enzim penting dalam darah yang dapat mengurai protein plasma terutama fibrin sehingga dapat menurunkan kekentalan darah (Lehninger, 1994). Sementara kondroitin sulfat adalah suatu derivat komponen tulang rawan. Kondroitin sulfat baik secara oral maupun injeksi dapat membantu meningkatkan gerakan sendi dan mengurangi rasa nyeri pada sendi. Kombinasi penggunaan glukosamin sulfat dan kondroitin sulfat menunjukkan efek yang potensial dalam merangsang produksi proteoglikan dan asam hialuronat serta menghambat enzim proteolitik yang dapat merusak tulang rawan (Hamijoyo, 2003). Oleh karena itu, ekstrak teripang dapat menyembuhkan radang sendi, rematik, dan osteoarthritis.

Teripang juga mengandung antioksidan berupa saponin glikosida. Komponen ini mempunyai stuktur yang serupa dengan senyawa aktif ginseng dan ganoderma. Senyawa anti kanker berupa terperoid, protein, saponin, dan polisakarida juga terdapat di dalam teripang. Hasil penelitian menunjukkan teripang mengandung senyawa aktif triterpen glikosida yang dapat menghambat pertumbuhan tumor pada sel limfoid, sel tumor paru manusia, sel tumor servix, dan melanoma tikus pada kisaran konsentrasi 0,38-0,46 $\mathrm{mg} / \mathrm{ml}$ (Fitriani, 2006). Teripang juga dilaporkan mengandung lektin yaitu suatu protein atau glikoprotein non-imunogenik yang dapat menghambat pertumbuhan kanker. Senyawa tersebut pada konsentrasi $50 \mu \mathrm{g}$ dapat menggumpalkan dan membunuh sel kanker.

Selain itu, teripang juga mengandung senyawa antibakteri yang cukup potensial. Hasil penelitian Ridzwan et al. (1995), menunjukkan bahwa ekstrak teripang dapat menghambat bakteri Streptococcus faecalis, S. viridans, S. pneumonia, Sthapilococcus auereus, dan Proteus mirabilis. Oleh karena itu, 
teripang juga dapat dimanfaatkan sebagai antiseptik tradisional. Pada penelitian lain menunjukkan bahwa lektin mempunyai efek tereupetik pada Human Immunodeficiency Virus (HIV). Hasil tes laboratorium dengan menggunakan sel limpfoid, menunjukkan bahwa lektin secara sempurna dapat menghalangi virus HIV (Darmananda, 2002).

\section{TEKNOLOGI PENGOLAHAN TERIPANG}

\section{Pengolahan teripang kering}

Teripang biasanya diolah dalam bentuk kering dan asap yang dilakukan oleh para nelayan pengolah tradisional dengan teknologi dan peralatan yang sederhana. Untuk mendapatkan kualitas teripang kering yang baik, maka proses pengolahan teripang harus memenuhi persyaratan tertentu. Tahapan pengolahan teripang meliputi penanganan bahan baku, pengeluaran isi perut, perebusan, penghilangan lapisan kapur, penyiangan, pengasapan, pengeringan, dan pengemasan.

\section{a. Pemilihan dan penanganan bahan baku}

Untuk memenuhi persyaratan komersial, idealnya bahan baku teripang berukuran $400-500 \mathrm{~g}$ dan dipanen dari daerah yang bebas polusi. Karena teripang merupakan produk ekspor dan hidup di dasar laut maka kemungkinan tercemar logam berat seperti merkuri $(\mathrm{Hg})$, kadmium $(\mathrm{Cd})$, dan timbal $(\mathrm{Pb})$ selalu ada. Untuk mendapatkan hasil olahan teripang yang bermutu tinggi, sebaiknya teripang diolah masih dalam keadaan hidup. Teripang biasanya dipanen dengan cara menyelam, dan segera setelah dipanen teripang ditempatkan dalam ember yang berisi air laut yang secara periodik diganti. Dengan cara ini, teripang dapat dipertahankan hidup selama 6-8 jam (Wibowo et al., 1997). Kalau hal ini tidak memungkinkan, maka teripang segera disiangi dan di es sehingga suhu dapat dipertahankan antara $0-2^{\circ} \mathrm{C}$.

\section{b. Pengeluaran isi perut teripang}

Pengeluaran isi perut teripang dapat dilakukan pada teripang mentah atau setelah direbus. Cara kedua lebih mudah dilakukan karena teksturnya lebih kenyal, namun seringkali selama perebusan isi perut pecah, sehingga cara ini tidak dianjurkan. Pengeluaran isi perut dilakukan dengan memasukkan tangkai kayu kecil ke lubang anus dan diputar-putar diseputar anus untuk memudahkan pengeluaran isi perut dengan cara menekan tubuh teripang. Cara yang lebih mudah dilakukan adalah dengan membelah bagian perut dengan menggunakan pisau yang tajam, kemudian mengeluarkan isi perutnya. Segera setelah isi perut dikeluarkan, teripang dicuci bersih pada bagian dinding perut sampai bebas dari darah dan sisa isi perut dengan menggunakan air tawar atau air laut yang bersih.

\section{c. Perebusan}

Perebusan teripang bertujuan untuk membuat tekstur teripang menjadi kenyal. Perebusan dilakukan dengan menggunakan air garam dengan konsentrasi 15\% selama 20-30 menit. Menurut Wibowo et al. (1997), untuk teripang pasir perebusan dilakukan menjadi 2 tahap yaitu perebusan dilakukan dengan memasukkan teripang ke dalam air laut biasa (suhu $26-28^{\circ} \mathrm{C}$ ), kemudian dipanaskan sampai suhu mencapai $70-80^{\circ} \mathrm{C}$. Pada perebusan pertama ini suhu dipertahankan selama 15 menit. Perebusan pertama diakhiri jika teripang yang tadinya gepeng menjadi gembung kembali. Perebusan tahap kedua dilakukan dengan cara memasukkan teripang pasir pada suhu hampir mendidih selama 20 menit. Perebusan ini dimaksudkan untuk memantapkan sehingga semua teripang menjadi kenyal teksturnya. Setelah perebusan selesai, dilakukan penirisan sampai tidak ada air yang menetes.

\section{d. Penghilangan lapisan kapur}

Penghilangan lapisan kapur dilakukan pada lapisan permukaan teripang yang mengandung kapur seperti pada teripang pasir. Menurut Wibowo et al. (1997) untuk membantu menghilangkan lapisan kapur dapat digunakan enzim proteolitik yang terdapat pada daun dan buah pepaya, umbi gadung, dan enzim papain "Paya" yang banyak dijual dipasaran. Teripang direbus dengan menambahkan enzim dalam bentuk daun/ buah pepaya sebanyak 7,5\% (b/v) atau enzim "Paya" sebesar 3,75\% (b/v). Yang perlu diperhatikan dalam penggunaan bahan tersebut adalah pengendalian suhu, karena suhu aktifitas enzim tersebut berkisar antara $55-65^{\circ} \mathrm{C}$. Perebusan dilakukan selama 60 menit. Penggunaan bahan kimia seperti $\mathrm{NaOH}$ (soda api) sebesar $1 \%$ dapat membantu pelepasan kapur dari kulit teripang. Setelah selesai perebusan, sisasisa kapur yang masih menempel digosok dan disikat sampai bersih.

\section{e. Pengasapan}

Pengasapan dilakukan untuk mengurangi kadar air serta memberikan bau fenol spesifik yang dikehendaki oleh konsumen. Alat yang digunakan untuk pengasapan sebaiknya berupa lemari asap sehingga proses pengasapan dapat berjalan dengan baik. Pengasapan dilakukan selama 10-20 jam dengan ketebalan asap sedang dengan suhu $60-80^{\circ} \mathrm{C}$ (Anon., 2007b). Sedangkan menurut Wibowo et al. 
(1997), pengasapan dilakukan menjadi 2 tahap. Tahap pertama adalah pengasapan tipis yang dilakukan pada suhu $70-90^{\circ} \mathrm{C}$ untuk mengurangi kadar air. Selanjutnya dilakukan pengasapan tebal selama 1-1,5 jam. Selama pengasapan teripang dibolak-balik sehingga asap merata. Untuk mendapatkan asap yang khas, selama pengasapan dapat ditambahkan serbuk gergaji dan daun jambu biji segar yang ditaburkan di atas bara arang sebagai bahan pengasap sehingga dapat menghasilkan teripang kering yang berkualitas tinggi (Anon., 2007b).

\section{f. Pengeringan}

Tahap akhir pengolahan teripang kering adalah pengeringan. Pengeringan dapat dilakukan dengan sinar matahari atau dengan menggunakan pengering mekanis (mechanical dyer). Teripang dijemur di atas para-para, apabila cuacanya panas maka penjemuran dapat dilakukan selama 2-3 hari sampai kadar air teripang kurang dari $20 \%$. Pengeringan dengan menggunakan pengering mekanis dengan suhu pengeringan yang sebaiknya disesuaikan dengan suhu panas matahari yaitu $\pm 50^{\circ} \mathrm{C}$.

\section{g. Pengemasan dan penyimpanan}

Teripang yang sudah kering kemudian dikemas dengan menggunakan karung plastik. Penggemasan teripang dengan menggunakan bekas karung beras menyebabkan teripang mudah hancur. Kemasan kemudian disusun di atas rak-rak dalam gudang dan tumpukan karung plastik tersebut ditutup dengan terpal pada bagian atasnya. Pada prinsipnya teripang harus disimpan pada suhu ruangan yang tidak terlalu tinggi dengan kelembaban yang rendah. Ruang yang terlalu lembab akan menyebabkan teripang mudah berjamur dan rusak karena sifatnya yang higroskopis karena kandungan garam serta kolagen yang bersifat menyerap air.

\section{Cara memasak teripang sebagai bahan pangan}

Teripang merupakan sajian istimewa bagi masyarakat Cina. Oleh karena kandungan nutrisinya yang lengkap, teripang digunakan untuk menjaga vitalitas tubuh. Teripang kering biasanya sebagai bahan campuran dalam berbagai macam masakan seperti capcay, sup, salad, dan masakan Cina lainnya. Sebelum dimasak, tekstur teripang harus dikembalikan seperti sebelum dikeringkan, yaitu dengan merendamnya di dalam air. Untuk mengurangi bau amis, teripang direndam dengan menggunakan air cucian beras selama 3 jam. Selama perendaman teripang dibesihkan dari kotoran yang menempel.
Teripang kemudian direbus dalam air mendidih selama 10 menit, kemudian diredam dengan air dingin selama 24-48 jam, sehingga diperoleh tekstur teripang seperti sebelum diasap. Teripang yang sudah direndam selanjutnya dapat diolah sebagai bahan campuran dalam berbagai masakan dan siap untuk disantap.

\section{Pengolahan ekstrak teripang sebagai bahan nutraceutical}

Selain diolah menjadi bahan pangan, teripang dapat diolah menjadi makanan suplemen. Untuk mendapatkan ekstrak teripang yang baik maka bahan teripang yang akan diolah dipilih sesuai dengan standar mutu yaitu teripang segar yang berwarna coklat cerah dan tidak berbau amis. Di Malaysia, pengolahan teripang menjadi ekstrak teripang dilakukan menjadi 2 tahap. Tahap pertama adalah ekstraksi yang biasanya dilakukan oleh nelayan dan tahap kedua penyaringan yang dilakukan oleh industri farmasi pengolah ekstrak teripang. Di Malaysia, bertebaran puluhan industri ekstraksi teripang skala rumah tangga sampai besar yang berpusat di Pulau Langkawi yang dilakukan oleh nelayan. Ekstrak teripang kemudian dijual ke pabrik farmasi yang akan memproses lebih lanjut bahan tersebut menjadi makanan suplemen. Ekstraksi teripang dimulai dari seleksi bahan yang memenuhi standar, kemudian dibelah untuk mengeluarkan isi perutnya, dan dicuci sampai bersih. Daging teripang yang sudah bersih kemudian direbus selama 3 jam sehingga daging hancur dan diperoleh filtrat yang berwarna coklat. Filtrat kemudian disimpan dan didiamkan selama 1 bulan sehingga air yang berwarna coklat menjadi jernih. Air rebusan teripang kemudian diolah lebih lanjut oleh industri farmasi. Ekstrak teripang kemudian disaring dengan menggunakan berbagai tahap penyaringan. Penyaringan tahap pertama dilakukan untuk menghilangkan kotoran yang masih terlarut sehingga diperoleh filtrat yang berwarna kecoklatan. Penyaringan kedua dilakukan untuk menghilangkan garam serta bau sehingga larutan berubah warna dari kecoklatan menjadi kekuningan. Tahap selanjutnya penyaringan dilakukan dengan metode penukaran ion sehingga larutan yang berwarna menjadi putih berkabut. Selanjutnya dilakukan sterilisasi dengan menggunakan sinar ultraviolet sehingga diperoleh larutan teripang yang steril dan higienis. Ekstraksi teripang dapat juga dilakukan dengan menggunakan pelarut organik seperti metanol, etanol, dan heksana. Jika digunakan pelarut metanol dan etanol maka senyawa yang bersifat polar yang sifatnya larut dalam air yang akan larut, sedangkan jika mengunakan heksana maka senyawa yang diperoleh adalah yang bersifat non-polar, yang tidak larut dalam air. Di samping itu, teripang juga dapat diekstrak dengan menggunakan air dengan cara merebus teripang 
dalam larutan air. Ekstrak teripang kemudian diolah lebih lanjut dalam bentuk jelly, tablet, dan kapsul untuk dipasarkan sebagai suplemen.

\section{PENUTUP}

Dari uraian di atas dapat disimpulkan bahwa teripang yang selama ini baru diolah menjadi produk teripang kering dan asap ternyata mempunyai potensi sebagai suplemen dan obat karena kandungan nutrisinya yang lengkap sehingga dapat digunakan sebagai suplemen untuk mencegah berbagai macam penyakit. Melihat potensi pemanfaatannya yang cukup besar serta ketersediaan sumberdaya teripang dengan keragaman jenis spesies yang tinggi di Indonesia, seharusnya industri farmasi untuk mengolah teripang menjadi makanan suplemen berada di Indonesia. Hal ini juga didukung dengan meningkatnya kesadaran masyarakat akan kesehatan sehingga prospek pasar ekstrak teripang sangat menjanjikan. Selama ini teripang hanya diolah dalam bentuk kering dan di ekspor dengan nilai tambah yang relatif kecil bila dibandingkan dengan ekstrak teripang untuk suplemen. Sementara penelitian untuk mendapatkan senyawa bioaktif berbagai jenis teripang belum banyak dilakukan. Penelitian informasi senyawa bioaktif pada berbagai jenis teripang yang ada di Indonesia perlu ditingkatkan. Demikian juga budidaya teripang perlu digalakkan sehingga dapat mendorong tumbuhnya industri farmasi yang berbasis teripang di Indonesia. Peningkatan mutu produk olahan teripang kering asap perlu dilakukan melalui pembinaan dari instansi terkait, sehingga nilai produk olahannya dapat dihargai sama dengan produk olahan dari negara lain.

\section{DAFTAR PUSTAKA}

Admin. 2008. Riset Gamat di Malaysia dan Seluruh Dunia. Majalah On Line Trubus 7 Februari 2008. Diakses tanggal 23 Februari 2008.

Anonim. 2007a. Segudang manfaat dari Teripang. Warta Perikanan. Edisi Juli No 47.

Anonim. 2007b. Penanganan dan Pengolahan Teripang. Artikel-dkp.go.id. 5 pp.
Departemen Kelautan dan Perikanan. 2007c. Statistik Kelautan dan Perikanan Departemen Kelautan dan Perikanan RI 2006.

Anonymous. 2006b. Sea cucumber. www.haisom.com. Diakses tanggal 28 Maret 2008.

Alimudin. 2006a. Memproduksi Omega 3 di Tanaman. Artikel Iptek Bidang Biologi Pangan dan Kesehatan. $4 \mathrm{pp}$.

Daryatmo, S. 2006. Obat mujarab dari laut. Trubus Edisi Juli 2006.

Darmananda, S. 2002. Sea Cucumber. Institute for Traditional Medicine. Portland Oregeon. 2 pp.

Darsono, P. 2005. Teripang (Holothurians) Perlu Dilindungi. Makalah. Bidang Sumberdaya Laut. Puslit Oseanografi- LIPI Jakarta. 24 pp.

Fitriani, V. 2006. Khasiat Dibalik Resep Datuk. Trubus on line. Edisi Teripang untuk mengatasi penyakit maut. Diakses tanggal 28 Maret 2008.

Fredalina, B., Ridzwan, B.H., Abidin, Z.A., Kaswadi, M.A., Zaiton, H., Zali, I., Kittakoop, P., and Jais, A. M. 1999. Fatty Acid Composistions in Local Sea Cucumber, Stichopus chloronotus, for Wound Healing. General Pharmacology. Vol 33 (4). 337-340.

Hamijoyo, L. 2003. Glukosamine dan Chondroitin. Medika Holostik. 5 pp.

Hermansyah, Iman W., Riazkika, K., Fawnia, S., dan Fitriani. 2006. Obat Mujarab Dari Laut. Trubus On Line. Juli 2006. Diakses tanggal 28 Maret 2008.

Lehninger, A.L. 1994. Dasar-Dasar Biokimia. Alih Bahasa Thenawijaya. M. Penerbit Erlangga.

Murdjiyo, Fx. 1997. Kebijaksanaan Nasional Pengelolaan dan Pemanfaatan Sumberdaya Ikan Perairan Laut Indonesia. Makalah Seminar Nasional Perikanan. 1997. Taruna Sekolah Tinggi Perikaan Jakarta. 30 pp.

Ridzwan, B.H., Kaswandi, M., Azman, Y., and Fuad, M. 1995. Screening for antibacterial agents in three species of sea cucumbers from coastal areas of Sabah. General Farmakology Vol 26 . No 7 p.15391543.

Wibowo, S., Yunizal, Setiabudi, E., Erlina, M.D., dan Tazwir. 1997. Teknologi Penanganan dan Pengolahan Teripang (Holothuroidea). Instalasi Penelitian Perikanan Laut Slipi Balai Penelitian Perikanan Laut. Puslitbangkan. Jakarta. 37 pp.

Zhang, E. 1988. Chinese Medicated Diet. Publishing House of Shanghai College of Tradisional Chinese, Shanghai. 3 pp. 